\title{
PENGARUH PENGGUNAAN TEPUNG CACING TANAH (Lumbricus rubellus) TERHADAP KECERNAAN BAHAN KERING DAN BAHAN ORGANIK RANSUM DOMBA LOKAL JANTAN
}

\section{THE INFLUENCE OF EARTHWORM FLOUR (Lumbricus rubellus) USE TO DIGESTION OF DRY MATTER and ORGANIC MATTER DIGESTIBILITY LOCAL MALE SHEEP FEED}

\author{
Ginda Sihombing, Wara Pratitis dan Ginanjar Arya Dewangga \\ Jurusan Peternakan, Fakultas Pertanian UNS
}

\begin{abstract}
ABSTRAK
Pengembangan usaha ternak domba dilakukan sebagai salah satu komoditas penghasil daging untuk memenuhi kebutuhan. Untuk meningkatkan produktivitas daging domba, diperlukan adanya kualitas pakan yang menunjang. Salah satunya menggunakan pakan dengan campuran tepung cacing tanah (Lumbricus rubellus). Penelitian ini bertujuan untuk mengetahui pengaruh penggunaan tepung cacing tanah (Lumbricus rubellus) terhadap kecernaan bahan kering dan bahan organik ransum domba lokal jantan. Penelitian ini dilaksanakan di kandang penelitian Jurusan Peternakan Fakultas Pertanian Universitas Sebelas Maret yang berlokasi di Desa Jatikuwung, Kecamatan Gondangrejo, Kabupaten Karanganyar.. Penelitian dilaksanakan dari tanggal 28 Desember 2008 sampai 22 Februari 2009. Penelitian menggunakan 12 ekor domba lokal jantan dengan bobot badan rata-rata 13,82 $\pm 0,73 \mathrm{~kg} / \mathrm{ekor}$. Ransum yang diberikan sebesar $6 \%$ dari bobot badan yang terdiri dari hijauan dan konsentrat dengan perbandingan 70:30 persen (dasar BK). Konsentrat yang digunakan berupa konsentrat campuran yang terdiri dari bekatul, bungkil kedelai, tepung jagung, tepung cacing dan premix. Sedangkan hijauan yang diberikan berupa rumput lapang. Ransum perlakuan yang digunakan masing- masing adalah rumput lapang $70 \%$, konsentrat $30 \%$ (P0); rumput lapang $70 \%$, konsentrat $28 \%$, tepung cacing $2 \%(\mathrm{P} 1)$; rumput lapang $70 \%$, konsentrat $26 \%$, tepung cacing $4 \%$ (P2) dan rumput lapang $70 \%$, konsentrat $24 \%$, tepung cacing 6\% (P3). Rancangan percobaan yang digunakan adalah Rancangan Acak Lengkap (RAL) pola searah dengan 4 level perlakuan (P0, P1, P2, dan P3). Masing-masing perlakuan terdiri dari 3 ulangan dan setiap ulangan terdiri dari satu ekor domba lokal jantan. Parameter yang diamati: Konsumsi Bahan Kering (BK), Konsumsi Bahan Organik (BO), Kecernaan Bahan Kering (BK), dan Kecernaan Bahan Organik (BO).

Hasil penelitian menunjukkan bahwa rerata dari keempat macam perlakuan (P0, P1, P2 dan P3) berturut-turut untuk konsumsi bahan kering 858,35; 876,57; 881,55 dan 887,58 (gram/ekor/hari), konsumsi bahan organik 670,32; 682,04; 686,16 dan 689,03 (gram/ekor/hari), kecernaan bahan kering 55,$17 ; 59,51 ; 57,19$ dan 58,84 persen dan kecernaan bahan organik 66,28; 69,09; 67,21 dan 68,12 persen.

Hasil analisis variansi menunjukkan bahwa konsumsi bahan kering, konsumsi bahan organik, kecernaaan bahan kering, dan kecernaan bahan organik adalah berbeda tidak nyata $(\mathrm{P} \geq 0,05)$. Kesimpulan dari penelitian ini adalah penggunaan tepung cacing tanah (Lumbricus rubellus) dalam ransum hingga $6 \%$ dari total konsentrat tidak mempengaruhi konsumsi dan kecernaan bahan kering dan bahan organik, namun mampu mempertahankan kualitas pakan ransum domba lokal jantan.
\end{abstract}

Kata kunci : domba lokal jantan, tepung cacing tanah, kecernaan

\section{ABSTRACT}

The development of sheep livestock is done as a comodity producer to meet the need of the meat. To increase the productivity of the sheep, the feed have a certain quality with the mix of worm flour. This research aims to determine the influence of the use of worm flour (Lumbricus rubellus) concerning to dry and organic matter digestibility lokal male sheeps feed. This research was conducted in the enclosure of research at the Faculty of Agriculture, Animal Husbandry Department of the Universitas Sebelas Maret Surakarta which is located in the Village Jatikuwung, Gondangrejo District, District Karanganyar. Research was conducted from December 28th, 2008 to February 22nd, 2009 using the 12 local male tail sheep with body weight on average $13.82 \pm 0.73 \mathrm{~kg} /$ head. Feed given at $6 \%$ of body weight consist of a concentrate forage and comparison with 70:30 per cent (basic dry matter). Utilized of the concentrate 
made of a mixture that consist of bekatul, oilcake soybean, corn flour, worm flour, and premix while forage given a field grass. Feed treatment used field grass 70\%, concentrate 30\% (P0); field grass 70\%, $28 \%$ concentrate, worm flour 2\% (P1); field grass 70\%, 26\% concentrate, worm flour 4\% (P2) and 70\% field grass, 24\% concentrate, worms flour 6\% (P3). Experimental design used was the Complete Random Design (CRD) pattern, the direction of the 4-level treatment (P0, P1, P2, and P3). Each treatment consist of 3 test replications and the replications each of one local male sheep. Parameter observed: dry matter consumption (DMC), organic matter consumption (OMC), dry matter digestibility (DMD), and organic matter digestibility $(O M D)$.

Results of research indicate that the average of the four treatment (P0, P1, P2 and P3) respectively for the dry matter consumption 858.35, 876.57, 881.55 and 887.58 (grams/ head/ day), organic matter consumption 670.32, 682.04, 686.16 and 689.03 (grams/ head/ day), dry matter digestibility 55.17, 59.51, 57.19 and 58.84 percent and organic matter digestibility 66.28, 69.09, 67.21 and 68.12 percent.

Variansi analysis results show that the dry matter consumption, organic matter consumption, dry matter digestibility, and organic matter digestibility is not significantly different $(P \geq 0.05)$. Conclusion of this research is the use of worm flour (Lumbricus rubellus) in feed up to $6 \%$ of the total concentration does not affect consumption and digestibility of dry and organic matter, but able to maintain the quality of local male sheep feed.

Keywords : lokalmale sheep, earthworms flour, digestibility

\section{PENDAHULUAN}

Pengembangan usaha ternak domba dilakukan sebagai salah satu komoditas penghasil daging. Jenis domba yang sudah banyak dipelihara ada dua jenis yaitu domba ekor gemuk dan domba ekor tipis atau domba lokal. Salah satu jenis ternak domba yang populer dan tersebar luas di Indonesia adalah domba lokal seperti domba Garut atau domba Parahyangan. Domba lokal merupakan domba asli Indonesia. Tubuhnya relatif kecil, kepala ringan dan kecil, telinga pendek dan tegak lurus mengarah ke atas depan (Murtidjo, 1993). Domba lokal atau domba kacang adalah domba yang tubuhnya kecil dan warna bulunya bermacam-macam seperti putih, atau putih kecoklatan. Kadangkadang terdapat lebih dari satu warna pada seekor domba. Domba jantan bertanduk kecil sedangkan domba betina tidak bertanduk. Berat domba jantan 30-40 kg sedangkan domba betina berkisar 15-20 kg, hasil dagingnya hanya sedikit. Domba dapat bertahan hidup di daerah kurang baik dan pertumbuhannya sangat lamban (Sumoprastowo, 1993).

Menurut Davendra (1993), pemeliharaan domba di Indonesia dilakukan secara tradisional dengan pemberian pakan hijauan dan sedikit sekali pakan penguat (konsentrat). Menurut Williamson dan Payne (1993), pakan ternak terdiri dari dua jenis yaitu pakan hijauan dan pakan konsentrat. Pemberian ransum berupa kombinasi kedua bahan itu akan memberi peluang terpenuhinya nutrien yang dibutuhkan. Konsentrat untuk domba umumnya disebut pakan penguat atau bahan baku pakan yang memiliki kandungan serat kasar kurang dari 18\% dan mudah dicerna. Konsentrat terdiri dari biji-bijian yang digiling halus, seperti jagung, bungkil kelapa, bungkil kedelai, dan dedak (Murtidjo, 1993). Menurut Tillman et al (1998), konsentrat adalah pakan yang mengandung energi relatif tinggi, serat kasar rendah sebesar 3,6\%, BETN tinggi, dan mudah dicerna oleh ternak. Pemberian konsentrat dengan kualitas dan kuantitas yang memenuhi syarat dapat menghasilkan bobot dan persentase karkas yang tinggi. Untuk meningkatkan produktivitas ternak domba dibutuhkan pakan yang memiliki kandungan protein yang tinggi. Salah satu bahan pakan berprotein tinggi adalah cacing tanah dimana penggunaannya dalam bentuk tepung.

Cacing tanah termasuk dalam golongan makhluk invertebrata, artinya mahluk yang tidak memiliki tulang, akan tetapi ia mampu bergerak yang dilakukan otot-otot yang melingkari tubuhnya (Soenanto, 2000). Manfaat dari cacing tanah dapat membantu kehidupan manusia, diantaranya sebagai penghasil pupuk organik, bahan baku obat dan kosmetika, dan juga dimanfaatkan sebagai bahan pakan ternak. Cacing tanah sebagai bahan pakan ternak digunakan dalam bentuk tepung dicampur dengan bahan lainnya dan penggunan dalam ransum tergantung pada jenis ternaknya, sekitar 10-25\% (Palungkun, 1999).

Hasil analisa didapatkan bahwa kandungan protein tepung cacing tanah sebesar $60-70 \%$, lemak kasar $7 \%$, kalsium $0,55 \%$, fosfor $1 \%$, serat kasar 1,08\% (Palungkun, 1999). Pada penelitian 
ternak ayam pedaging, didapatkan hasil bahwa penggunaan tepung cacing tanah pada taraf $10 \%$ dalam ransum sampai umur 8 minggu menghasilkan bobot hidup yang lebih tinggi dibandingkan dengan penggunaan ransum komersial dan PBBH didapatkan hasil 40,4 g/ekor/hari (Anonimus, 2008). Berdasar uraian di atas, maka perlu dilakukan penelitian tentang pengaruh penggunaan tepung cacing tanah (Lumbricus rubellus) dalam ransum terhadap kecernaan bahan kering dan bahan organik pada domba lokal jantan.

\section{METODOLOGI}

Bahan dan alat yang digunakan dalam penelitian ini adalah domba lokal jantan dengan bobot badan $13,82 \pm 0,73 \mathrm{~kg}$ sebanyak 12 ekor, ransum yang digunakan terdiri dari pakan hijauan (rumput lapang) dan pakan konsentrat (bungkil kedelai, bekatul, tepung jagung, dan premix) dan tepung cacing tanah sebagai pakan perlakuan. Adapun kebutuhan nutrien domba, susunan konsentrat, kandungan nutrien dan susunan ransum dapat dilihat pada tabel 1, 2, 3 dan 4 . Kandang yang digunakan berjumlah 12 buah, yaitu kandang panggung individu terbuat dari kayu dengan ukuran $100 \mathrm{~cm}$ x $75 \mathrm{~cm}$ x $120 \mathrm{~cm}$ dan peralatan yaitu tempat pakan rumput lapang dari papan kayu sedangkan tempat konsentrat dan air terbuat dari ember plastik. Timbangan elektronik merk ideal life dengan kapasitas $5 \mathrm{~kg}$ dengan kepekaan 1 gram untuk menimbang pakan, sisa pakan, dan feses. Timbangan gantung kapasitas $25 \mathrm{~kg}$ dengan kepekaan $0,1 \mathrm{~kg}$ untuk menimbang domba. Lampu pijar sebagai alat penerangan kandang. Peralatan lain yang digunakan yaitu sapu lidi, sabit, selang air, sekop, dan thermometer.

Penelitian ini dilakukan secara eksperimental menggunakan Rancangan Acak Lengkap (RAL) pola searah dengan 4 macam perlakuan. Setiap perlakuan terdiri dari 3 ulangan dan setiap ulangan terdiri dari satu ekor domba lokal jantan. Ransum perlakuan terdiri dari rumput lapang dan konsentrat dengan susunan rumput lapang 70\%, konsentrat 30\% (P0); rumput lapang $70 \%$, konsentrat $28 \%$, tepung cacing 2\% (P1); rumput lapang $70 \%$, konsentrat $26 \%$, tepung cacing 4\% (P2) dan rumput lapang $70 \%$, konsentrat 24\%, tepung cacing 6\% (P3). Peubah penelitian yang diamati adalah Konsumsi Bahan Kering, Konsumsi Bahan Organik, Kecernaan Bahan Kering, dan Kecernaan Bahan Organik. Pelaksanaan penelitian ini dibagi menjadi 3 tahap yaitu tahap adaptasi, tahap pemeliharaan dan tahap koleksi data. Tahap adaptasi dilakukan selama 2 minggu meliputi penimbangan bobot badan awal, adaptasi lingkungan, dan pakan. Tahap pemeliharaan dilaksanakan selama enam minggu setelah adaptasi dan di akhir penelitian dilaksanakan tahap koleksi data selama tujuh hari meliputi pengukuran konsumsi pakan dan feses. Koleksi feses dilakukan dengan menimbang feses yang dihasilkan selama 24 jam. Feses yang dihasilkan diambil $10 \%$ untuk dikeringkan di bawah panas matahari yang kemudian dimixer dan selanjutnya dicampur (dikomposit) sampai homogen untuk setiap ternak.Pada tahap koleksi data pemberian pakan sesuai dengan perlakuan masing-masing pada pukul 07.00 WIB dan 14.00 WIB untuk pakan konsentrat, pukul 08.00 WIB dan 15.00 WIB untuk hijauan. Sedangkan air minum disediakan secara ad libitum.

Tabel 1. Kebutuhan nutrien untuk domba berat badan $15 \mathrm{~kg}$

\begin{tabular}{lc}
\hline \multicolumn{1}{c}{ Nutrien } & Kebutuhan \\
\hline Total digestible nutrient (TDN) \% & 55,00 \\
Protein Kasar (PK) \% & 12,50 \\
Kalsium (Ca) \% & 0,31 \\
Fosfor (P) \% & 0,32 \\
\hline
\end{tabular}

Sumber : Ranjhan (1980)

Tabel 2. Kandungan nutrien bahan penyusun konsentrat

\begin{tabular}{|c|c|c|c|c|c|c|}
\hline \multirow{2}{*}{ Bahan Pakan } & TDN & PK & LK & SK & $\mathrm{Ca}$ & $\mathrm{P}$ \\
\hline & $\%$ & $\%$ & $\%$ & $\%$ & $\%$ & $\%$ \\
\hline Bekatul $^{1)}$ & 49 & 9.1 & 4.0 & 2.5 & 0.03 & 0.26 \\
\hline Tp. Jagung ${ }^{1)}(16 \%)$ & 72 & 9.7 & 6.9 & 4.3 & 0.05 & 0.63 \\
\hline Bk. Kedelai ${ }^{1)}(10 \%)$ & 86 & 41.3 & 4.9 & 5.3 & 0.24 & 0.56 \\
\hline Premix $^{1)} \quad(2 \%)$ & - & - & - & - & 25 & 20 \\
\hline
\end{tabular}


Tabel 3. Kandungan nutrien bahan penyusun ransum

\begin{tabular}{|c|c|c|c|c|c|c|c|}
\hline \multirow{2}{*}{ Bahan Pakan } & BK & TDN & PK & LK & SK & $\mathrm{Ca}$ & $\mathrm{P}$ \\
\hline & $\%$ & $\%$ & $\%$ & $\%$ & $\%$ & $\%$ & $\%$ \\
\hline Rumput lapang & $32.80^{1)}$ & $58.02^{3)}$ & $11.28^{1)}$ & $1.61^{1)}$ & $24.17^{1)}$ & $0.37^{5)}$ & $0.23^{5)}$ \\
\hline Konsentrat & $89.92^{2)}$ & $64.32^{3)}$ & $13.74^{2)}$ & $6.17^{2)}$ & $11.53^{2)}$ & $0.55^{4)}$ & $0.74^{4)}$ \\
\hline Tp.Cacing tanah & $92.48^{2)}$ & $91.11^{3)}$ & $50.02^{2)}$ & $10.66^{2)}$ & $2.84^{2)}$ & $0.55^{6)}$ & $1^{6)}$ \\
\hline \multicolumn{8}{|c|}{$\begin{array}{l}\text { Sumber } \quad{ }^{1)} \text { Hasil Analisis Laboratorium Teknologi Pangan dan Hasil Pertanian Universitas Gadja } \\
{ }^{2)} \text { Hasil Analisis Laboratorium Biokimia Nutrisi Fakultas Peternakan Universitas Gadjal } \\
{ }^{3)} \text { Hasil perhitungan menurut Hartadi et al., (1997) } \\
{ }^{4)} \text { Hasil perhitungan tabel } 2 \\
{ }^{5)} \text { Susilo (2007) } \\
{ }^{6)} \text { Palungkun (1999) }\end{array}$} \\
\hline \multicolumn{8}{|c|}{ Tabel 4. Susunan ransum dan kandungan nutrien ransum berdasar perlakuan } \\
\hline \multirow{2}{*}{\multicolumn{2}{|c|}{ Bahan pakan }} & \multicolumn{6}{|c|}{ Perlakuan } \\
\hline & & $\mathrm{P}$ & & $\mathrm{P} 1$ & $\mathrm{P} 2$ & & P3 \\
\hline \multicolumn{8}{|c|}{ 1. Komposisi ransum } \\
\hline \multicolumn{2}{|c|}{ Rumput lapang } & \multicolumn{2}{|c|}{$70 \%$} & $70 \%$ & \multicolumn{2}{|c|}{$70 \%$} & $70 \%$ \\
\hline \multicolumn{2}{|l|}{ Konsentrat } & \multicolumn{2}{|c|}{$30 \%$} & $28 \%$ & \multicolumn{2}{|c|}{$26 \%$} & $24 \%$ \\
\hline \multicolumn{2}{|c|}{ Tp. Cacing Tanah } & \multicolumn{2}{|c|}{0} & $2 \%$ & \multicolumn{2}{|c|}{$4 \%$} & $6 \%$ \\
\hline \multicolumn{8}{|c|}{ 2.Kandungan Nutrien } \\
\hline \multicolumn{2}{|c|}{ Energi (TDN) } & \multicolumn{2}{|c|}{59.91} & 61.73 & \multicolumn{2}{|c|}{63.55} & 65.38 \\
\hline \multicolumn{2}{|c|}{ Protein Kasar (PK) } & \multicolumn{2}{|c|}{11.98} & 12.98 & \multicolumn{2}{|c|}{13.98} & 14.98 \\
\hline \multicolumn{2}{|c|}{ Lemak Kasar (LK) } & \multicolumn{2}{|c|}{2.97} & 3.18 & \multicolumn{2}{|c|}{3.40} & 3.62 \\
\hline \multicolumn{2}{|c|}{ Serat Kasar (SK) } & \multicolumn{2}{|c|}{20.38} & 20.43 & \multicolumn{2}{|c|}{20.49} & 20.54 \\
\hline \multicolumn{2}{|l|}{ Kalsium $(\mathrm{Ca})$} & \multicolumn{2}{|c|}{0.42} & 0.42 & \multicolumn{2}{|c|}{0.42} & 0.42 \\
\hline \multicolumn{2}{|l|}{ Phospor (P) } & \multicolumn{2}{|c|}{0.38} & 0.39 & \multicolumn{2}{|l|}{0.39} & 0.40 \\
\hline
\end{tabular}

Sumber : Hasil perhitungan tabel 3

\section{HASIL DAN PEMBAHASAN}

\section{Konsumsi Bahan Kering}

Rerata konsumsi bahan kering domba lokal jantan selama penelitian (Tabel 5) berturut-turut dari P0, P1, P2, dan P3 adalah 858,35; 876,57; 881,55; dan 887,58 g/ekor/hari. Hasil analisis variansi menunjukkan bahwa konsumsi bahan kering keempat macam perlakuan berbeda tidak nyata, artinya bahwa penambahan tepung cacing tanah dalam ransum sampai enam persen tidak berpengaruh terhadap konsumsi bahan kering domba. Hal ini disebabkan karena penambahan tepung cacing tanah dalam ransum sampai enam persen merubah kandungan nutrien dalam pakan, namun berdasarkan analisa statistik diperoleh hasil yang berbeda tidak nyata. Dapat diketahui dari perimbangan kandungan nutrien masingmasing perlakuan terjadi peningkatan (Tabel 4), yaitu untuk energi (TDN) berurutan dari P0-P3 59,$91 ; 61,73 ; 63,55 ; 65,38$ dan untuk protein, berurutan dari P0-P3 11,98; 12,98; 13,98; 14,98. Selain itu disebabkan pula tidak berubahnya palatabilitas dari pakan yang diberikan, walaupun pemberian tepung cacing tanah hingga taraf 6 persen. Sesuai dengan pendapat Reksohadiprodjo
(1991) bahwa besarnya konsumsi pakan menunjukkan palatabilitas dan nilai kualitas pakan tersebut, serta sesuai dengan pendapat Prawirodigdo (1995) bahwa palatabilitas mempengaruhi jumlah pakan yang dikonsumsi. Dalam hal ini ransum yang diberikan menggunakan tepung cacing tanah, memiliki palatabilitas yang relatif sama. Menurut Kartadisastra (1997), bahwa palatabilitas dicerminkan oleh organoleptiknya seperti kenampakan, bau, rasa, dan teksturnya. Kenampakan tepung cacing tanah yang menyerupai serbuk halus berwarna coklat, bau yang tidak terlalu amis, rasa asin. Pemberian tepung cacing dalam pakan tidak merubah kenampakan, bau, rasa dan tekstur dari pakan.

Pencampuran pakan yang homogen antara konsentrat dan tepung cacing tidak merubah kenampakan, bau maupun rasa dari pakan tersebut. Menurut Kartadisastra (1997), keadaan fisik dan kimiawi pakan ditunjukkan oleh kenampakan, bau rasa, dan tekstur menumbuhkan daya tarik dan merangsang ternak untuk mengkonsumsinya. Konsumsi BK biasanya dipengaruhi terutama oleh ukuran tubuh, jumlah energi yang terkandung dalam pakan dan laju 
pencernaan (Kearl, 1982) dan ditambahkan oleh Kartadisastra (1997), palatabilitas pakan, kadar protein kasar dan perlakuan pakan akan berpengaruh terhadap konsumsi bahan kering ternak ruminansia.

Dari hasil penelitian, penambahan tepung cacing tanah semakin meningkat pada masingmasing perlakuan, menyebabkan kandungan energi pakan meningkat pula. Energi digunakan mikrobia untuk berkembang sehingga populasinya meningkat. Lambung menjadi lebih cepat kosong dan merangsang ternak untuk mengkonsumsi pakan kembali. Menurut Parakkasi (1999), ternak akan berhenti makan ketika kapasitas lambung telah terpenuhi atau kebutuhan energi telah tercukupi. Konsentrasi energi yang terkandung didalam pakan berbanding terbalik dengan tingkat konsumsi. Semakin tinggi konsentrasi energi maka konsumsinya akan menurun (Kartadisastra, 1997).

\section{Konsumsi Bahan Organik}

Rerata konsumsi bahan organik domba lokal jantan selama penelitian (Tabel 6) berturutturut dari P0, P1, P2, dan P3 adalah 670,32; 682,04; 686,16; dan 689,03 g/ekor/hari. Hasil analisis variansi menunjukkan bahwa konsumsi bahan organik keempat macam perlakuan berbeda tidak nyata, artinya bahwa penambahan tepung cacing dalam ransum sampai dengan level enam persen tidak berpengaruh terhadap konsumsi bahan organik domba. Perbedaan yang tidak nyata dari konsumsi bahan organik ini disebabkan oleh konsumsi bahan kering yang berbeda tidak nyata pula. Jumlah konsumsi bahan kering akan berpengaruh terhadap konsumsi bahan organik, semakin meningkat konsumsi bahan kering maka konsumsi bahan organik juga meningkat dan sebaliknya (Kamal, 1994).

Konsumsi bahan organik berkorelasi positif dengan konsumsi bahan kering, hal ini disebabkan karena zat-zat yang terkandung dalam bahan organik terdapat pula pada bahan kering. Dalam hal ini kandungan bahan organik masingmasing perlakuan terjadi peningkatan kandungan nutrien, tetapi tidak berpengaruh terhadap konsumsi bahan organik. Menurut Tillman et al (1998), bahan kering terdiri dari bahan organik dan anorganik. Di dalam bahan organik itu sendiri terkandung lemak kasar, protein kasar, serat kasar, dan BETN, sedangkan bahan anorganik terdiri dari abu. Dapat dilihat pada tabel 4 bahwa kandungan nutrisi ransum perlakuan terjadi peningkatan, dengan kisaran untuk lemak kasar 2,97-3,62; protein kasar 11,9814,98; serat kasar 20,38-20,54; energi (TDN) 59,91-65,38, tetapi tidak mempengaruhi palatabilitas pakan itu sendiri, sehingga konsumsi bahan organiknya berbeda tidak nyata.

Tabel 5. Rerata konsumsi bahan kering (KBK) domba lokal jantan selama penelitian (g/ekor/hari)

\begin{tabular}{ccccc}
\hline \multirow{2}{*}{ Perlakuan } & \multicolumn{3}{c}{ Ulangan } & \multirow{2}{*}{ Rerata } \\
\cline { 2 - 4 } & 1 & 2 & 3 & 858,35 \\
P0 & 872,29 & 823,01 & 879,75 & 876,57 \\
P1 & 860,55 & 874,95 & 894,21 & 881,55 \\
P2 & 861,61 & 857,37 & 925,68 & 887,58 \\
P3 & 888,54 & 908,44 & 865,77 & \\
\hline
\end{tabular}

Tabel 6. Rerata konsumsi bahan organik (KBO) domba lokal jantan selama penelitian (g/ekor/hari)

\begin{tabular}{ccccc}
\hline \multirow{2}{*}{ Perlakuan } & \multicolumn{3}{c}{ Ulangan } & \multirow{2}{*}{ Rerata } \\
\cline { 2 - 4 } P0 & 1 & 2 & 3 & 670,32 \\
P1 & 681,24 & 642,75 & 686,97 & 682,04 \\
P2 & 668,52 & 680,89 & 696,70 & 686,16 \\
P3 & 670,02 & 668,37 & 720,10 & 689,03 \\
\hline
\end{tabular}

Tabel 7. Rerata kecernaan bahan kering (KcBK) domba lokal jantan selama penelitian (\%)

\begin{tabular}{ccccc}
\hline \multirow{2}{*}{ Perlakuan } & \multicolumn{3}{c}{ Ulangan } & \multirow{2}{*}{ Rerata } \\
\cline { 2 - 4 } & 1 & 2 & 3 & 55,17 \\
P0 & 55,75 & 54,44 & 55,31 & 59,51 \\
P1 & 62,88 & 56,89 & 58,76 & 57,19 \\
P2 & 64,38 & 52,11 & 55,07 & 58,84 \\
P3 & 60,22 & 59,69 & 56,62 & \\
\hline
\end{tabular}


Tabel 8. Rerata kecernaan bahan organik (KcBO) domba lokal jantan selama penelitian (\%)

\begin{tabular}{ccccc}
\hline \multirow{2}{*}{ Perlakuan } & \multicolumn{3}{c}{ Ulangan } & \multirow{2}{*}{ Rerata } \\
\cline { 2 - 4 } & 1 & 2 & 3 & 66,28 \\
P0 & 67,52 & 64,75 & 66,56 & 69,09 \\
P1 & 71,99 & 66,60 & 68,70 & 67,21 \\
P2 & 73,76 & 63,05 & 64,81 & 68,12 \\
P3 & 69,21 & 69,12 & 66,04 & \\
\hline
\end{tabular}

\section{Kecernaan Bahan Kering}

Rerata kecernaan bahan kering domba lokal jantan selama penelitian berturut-turut dari P0, P1, P2, dan P3 adalah 55,17; 59,51; 57,19; dan 58,84 persen (Tabel 7). Hasil analisis variansi menunjukkan bahwa kecernaan bahan kering keempat macam perlakuan berbeda tidak nyata, artinya bahwa penambahan tepung cacing tanah dalam ransum sampai dengan level enam persen tidak berpengaruh terhadap kecernaan bahan kering domba. Kecernaan bahan kering yang berbeda tidak nyata disebabkan karena konsumsi bahan kering masing-masing perlakuan juga berbeda tidak nyata. Hal ini sesuai dengan pendapat Zain (1999) bahwa tingkat konsumsi ransum mempengaruhi kecernaan, sehingga konsumsi yang berbeda tidak nyata antar perlakuan juga menyebabkan kecernaan yang berbeda tidak nyata. Tillman et al (1998) menyatakan bahwa daya cerna pakan erat hubungan dengan komposisi kimianya dan serat kasar mempunyai pengaruh yang terbesar terhadap daya cerna. Semakin tinggi kandungan serat kasar bahan pakan maka akan semakin rendah daya cernannya. Berdasar analisis laboratorium, pada tabel 4 diperoleh kandungan serat kasar yang relatif sama antar perlakuannya yaitu sebesar 20,38-20,54, akibatnya nilai kecernaan bahan keringnya juga menunjukan hasil yang berbeda tidak nyata. Hal ini dipertegas oleh Debora et al (2005) bahwa tinggi rendahnya kecernaan zat-zat makanan pada ternak ruminansia sangat dipengaruhi oleh kandungan serat kasar dan aktifitas mikrobia rumen terutama bakteri selulotik. Tillman et al (1998), menyatakan salah satu faktor yang mempengaruhi tingkat kecernaan adalah jumlah pakan yang dikonsumsi, dalam hal ini adalah bahan kering. Konsumsi bahan kering yang berbeda tidak nyata menyebabkan kecernaan bahan kering domba lokal jantan juga berbeda tidak nyata. Hal ini dikarenakan aktifitas mikroorganisme mengikuti bahan pakan yang dikonsumsi, sehingga jika konsumsi pakannya meningkat maka diduga pertumbuhan dan perkembangan mikrobianya juga meningkat (Kamal, 1994).
Perbedaan yang tidak nyata dari masingmasing perlakuan disebabkan pula karena kandungan protein pakan dari masing-masing perlakuan yaitu 11,98-14,98 (Tabel 4) terjadi perubahan kandungan nutrisi yang cenderung meningkat, tetapi berdasarkan hasil analisa statistik pengaruhnya didapatkan hasil yang berbeda tidak nyata. Hal ini disebabkan P0 (P kontrol) memiliki kandungan protein yang sudah bisa memenuhi kebutuhan protein pada domba. Penambahan tepung cacing dalam ransum hingga $6 \%$ mengakibatkan adanya kualitas protein yang tinggi namun mengakibatkan banyaknya protein yang tidak termanfaatkan. Didalam rumen terjadi proses pemecahan protein menjadi asam amino yang dilakukan oleh mikroorganisme. Mikroorganisme memecah protein dengan susunan asam amino yang sudah baik menjadi protein mikrobia dan amonia yang sebagian besar dikeluarkan melalui urine (Prawirokusumo, 1993).

Tepung cacing tanah mengandung asamasam amino yang terikat oleh ikatan peptida (H$\mathrm{N}-\mathrm{C}=\mathrm{O}$ ), sehingga termasuk jenis protein murni. Tillman et al (1998) menyatakan bahwa di dalam rumen beberapa protein murni tidak mampu menghindar dari pencernaan di retikulo rumen, dicerna oleh peptidase jasad renik dan diuraikan menjadi asam-asam amino yang dapat dipakai untuk sintesa protein jasad renik atau di deaminasi membentuk asam-asam organik, amonia dan $\mathrm{CO}_{2}$. Amonia yang terbentuk pada deaminasi dapat dikombinasikan dengan asam organik alfa keto membentuk asam-asam amino baru yang dapat dipakai untuk mensintesa protein jasad renik atau diabsorbsi ke sirkulasi potal dan dibawa ke hati, kemudian hati memakainya untuk membentuk urea yang nantinya masuk sirkulasi peredaran darah. Sebagian besar urea difiltrasi keluar oleh ginjal dan kemudian dikeluarkan bersama dengan urine. Sehingga perlu dilakukan teknologi protein by pass untuk memproteksi pakan dengan kandungan protein tinggi agar tidak didegradasi di rumen namun langsung datang pada proses digesti enzimatik didaerah abomasum atau usus halus (Prawirokusumo, 1993). 


\section{Kecernaan Bahan Organik}

Rerata kecernaan bahan organik domba lokal jantan selama penelitian berturut-turut dari P0, P1, P2, dan P3 adalah 66,28; 69,09; 67,21; dan 68,12 masing-masing dalam persen (Tabel 8). Hasil analisis variansi menunjukkan bahwa kecernaan bahan organik keempat macam perlakuan berbeda tidak nyata, artinya bahwa penambahan tepung cacing dalam ransum sampai dengan level enam persen tidak berpengaruh terhadap kecernaan bahan organik domba. Kecernaan bahan organik yang berbeda tidak nyata diakibatkan oleh tingkat konsumsi bahan organik masing-masing perlakuan yang juga berbeda tidak nyata. Tillman et al. (1998) menyatakan salah satu faktor yang mempengaruhi kecernaan adalah jumlah pakan yang dikonsumsi, dan Soeparno (1992) menambahkan tingkat konsumsi pakan juga berpengaruh terhadap kecernaan bahan kering dan bahan organik. Besarnya konsumsi bahan organik akan berpengaruh terhadap ketersediaan energi dalam rumen untuk pertumbuhan mikrobia rumen. Pertumbuhan mikrobia rumen berhubungan dengan kerja optimal mikrobia yang nantinya berpengaruh terhadap kecernaan ternak (Kamal, 1994). Kecernaan bahan organik yang berbeda nyata juga bisa disebabkan karena kecernaan bahan keringnya berbeda tidak nyata pula. Hal ini disebabkan kecernaan bahan kering dan bahan organik saling berhubungan, sebab bahan pakan berdasarkan komposisi kimianya dibedakan menjadi bahan anorganik (abu) dan bahan organik (Tillman et al, 1998).

Bahan organik terdiri dari lemak kasar, serat kasar, protein kasar, dan BETN, dimana karbohidrat (SK dan BETN) difermentasi menghasilkan VFA yang sebagian diserap ternak sebagai sumber energi dan sebagian lagi bersama dengan $\mathrm{NH}_{3}$ (amonia) hasil degradasi dari protein kasar digunakan untuk sintesis protein mikroba. Berdasarkan hasil analisis laboratorium dapat diketahui bahwa besarnya kandungan bahan organik (BO) konsentrat adalah 78,18\% dan rumput lapang sebesar $78,10 \%$ sehingga diperoleh kecernaan BO pada tabel 8, perlakuan P0, P1, P2, dan P3 tidak jauh berbeda, secara berturut-turut adalah $66,28 \%, 69,09 \%, 67,21 \%$, dan $68,12 \%$. Diduga bahwa asupan $\mathrm{N}$-amonia dan energi (VFA) dari bahan organik yang masuk ke dalam rumen sebagai media tumbuh mikroba hampir sama banyaknya, akibatnya kecernaan bahan organik ransum domba lokal jantan juga berbeda tidak nyata. Kamal (1994) menyatakan bahwa mikroorganisme di dalam rumen dapat membentuk protein tubuhnya dari peptida, asam amino, ataupun dari senyawa $\mathrm{N}$ sederhana berupa ammonia atau nitrogen non protein yang lain. Untuk keperluan tersebut maka mikroorganisme membutuhkan sumber energi, terutama berupa karbohidrat yang mudah dicerna yaitu pati atau gula.

\section{KESIMPULAN DAN SARAN}

Berdasarkan hasil pembahasan pada penelitian ini disimpulkan bahwa penambahan tepung cacing tanah sampai taraf enam persen dari total konsentrat dalam ransum tidak mempengaruhi konsumsi dan kecernaan bahan kering dan bahan organik domba lokal jantan.Disarankan untuk penelitian dengan penambahan tepung cacing tanah dalam ransum, menggunakan jenis ternak selain ternak ruminansia. Karena penambahan bahan pakan dengan kandungan protein tinggi tidak efektif untuk jenis ternak ruminansia.

\section{DAFTAR PUSTAKA}

Anonimus. 2007. Budidaya Ternak Domba,. http://www.iptek.net.id/ind/warintek/ diakses pada 22 Desember 2007.

Anonimus,2008. Budidaya Cacing Tanah. www.aagos.ristek.go.id/ diakses pada 2 Februari 2009.

Anonimus, 2008. http://www.digilib.ui.edu/opac/themes/libri 2/ diakses pada 2 Februari 2009.

Bappenas. 2000. http://www.ristek.go.id. Diakses Juni 2007.

Davendra, C dan M. Burns. 1993. Kambing dan Domba di Asia dalam Produksi Kambing dan Domba di Indonesia. Penerjemah IDK. Harya Putra. Penerbit Institut Teknologi Bandung. Bandung.

Debora, KH., Nenobais, M., Jacobnulik dan Katipana, NGF. 2005. Pengaruh Probiotik Terhadap Kemampuan Cerna Mikroba Rumen Sapi Bali. http://peternakan.litbangdeptan.go.id/. Diakses pada hari Jumat, tanggal 19 Desember 2008.

Forbes, J.M., 1986. The Voluntary Food Intake.Butter Words. London., pp. 6-14.

Gaspersz, Vincent. 1994. Metode Perancangan Percobaan.CV Armico. Bandung.

Hartadi, H., S Reksohadiprojo,dan A. D. Tilman. 1997. Tabel Komposisi Pakan Untuk Indonesia. Gadjah Mada University Press. Yogyakarta. 
Ismail, L.A. dan Pardi, 2000. Pengaruh Kombinasi Konsentrat dengan Daun Gamal dalam Ransum Terhadap Bobot badan Domba Lokal Jantan. Oryza (Majalah Ilmiah Universitas Mataram), Vol 5 No 20, Mataram University Press, Mataram.

Kamal, M., 1994. Nutrisi Ternak 1. Laboratorium Makanan Ternak Jurusan Nutrisi dan Makanan Ternak Fakultas Peternakan Universitas Gadjah Mada. Yogyakarta.

Kartadisastra, H.R., 1997. Penyediaan dan Pengelolaan Pakan Ternak Ruminansia (Sapi, Kerbau, Domba, Kambing). Kanisius. Yogyakarta.

Kearl, L.C., 1982. Nutrient Requirements of Ruminant in Developing Countries. International Feedstuff. Institute Utah Agricultural Experiment Station. Utah State University. Utah.

Mulyono, S., 1998. Teknik Pembibitan Kambing dan Domba. Penebar Swadaya, Jakarta.

Mulyono, S dan B. Sarwono, 2004. Beternak Domba Prolifik. Penebar Swadaya, Jakarta.

Murtidjo, B. A., 1993. Beternak Domba. Kanisius. Yogyakarta.

Mukhtar, A., 2006. Ilmu Produksi Ternak Perah. Lembaga Pengembangan Pendidikan (LPP) dan Universitas Sebelas Maret Press. Surakarta.

Nation Research Council, 1985. Nutrient Requirements of Sheep. Nutrient Requirements of Domestic Animal. Nation Academy Press, Washington DC.

Palungkun, R. 1999. Sukses Beternak Cacing Tanah (Lumbricus rubellus). Penebar Swadaya. Jakarta.

Parakkasi, A., 1999. Ilmu Nutrisi dan Makanan Ternak Ruminansia. UI Press. Jakarta.

Prawirodigdo, S.,D.M dan D. Andayani. 1995. Subtitusi Bungkil Kedelai dengan Bungkil Biji Kapok (Ceip petandra) dalam Ransum Kelinci Sedang Tumbuh. Jurnal Ilmiah ternak Klepu. Balitbag Pertanian. Deptan 1 (3). 26-31.

Prawirokusumo, S., 1993. Ilmu Gizi Komparatif. BPFE. Yogyakarta.

Ranjhan, S.K., 1980. Animal Nutrition and Feeding Practise in India. Vikan Publicing House PVTLtd. New Delhi.

Setala, J., 1983. The nilon bag technique in the determination of ruminal feed protein degradation. J. Sci. Agr. Soc. Finland. 55:1-78.

Siregar, S., 1994. Ransum Ternak Ruminansia. Penebar Swadaya. Jakarta.
Soedjono, M dan K.A. Santosa, 1991. Pemanfaatan zeolit di bidang peternakan. Kumpulan Makalah Seminar Zeo Agroindustri 18-19 Juli 1991. Bandung.

Soenanto, H. 2000. Budidaya Cacing Tanah (Lumbricus rubellus). CV. Aneka. Solo.

Soeparno, 1992. Ilmu dan Teknologi Daging. Gadjah Mada University Press. Yogyakarta.

Subagyo. 2008. Buku diktat mata kuliah Ilmu Ternak Potong dan Kerja. Jurusan Peternakan Fakultas Pertanian. Universitas Sebelas Maret. Surakarta.

Sugeng, Y, 2002. Sapi Potong. Penebar Swadaya. Jakarta.

Sumoprastowo, R.M., 1993. Beternak Domba Pedaging dan Wol. Bhratara, Jakarta.

Susilo, R. 2007. Pengaruh PenggunaanJerami Bawang Merah (Alium ascalonicum) sebagai Pakan Suplemen dalam Ransum Terhadap Kecernaan Bahan Kering, Bahan organik Domba Lokal Jantan. Skripsi S1. Fakultas Pertanian UNS. Surakarta.

Tillman A.D., H. Hartadi, S. Reksohadiprojo, S. Prawirokusumo, dan S. Lebdosoekojo, 1998. Ilmu Makanan Ternak Dasar. Gadjah Mada university Press, Yogyakarta.

Van Soest, P.J., 1994. Nutritional ecology of the ruminant.pp. 337-370. Cornell University; Ithaca and London.

Wariata,W. 2000, Peluang Penerapan Iptek dalam Pengembangan Ternak Domba Ditinjau dari Segi Anatomi dan Fisiologi Reproduksi. Oryza (Majalah Ilmiah Universitas Mataram). Vol 5 No 20. Mataram University Press. Mataram.

Williamson, G dan W.J.A Payne. 1993. Pengantar Peternakan di Daerah Tropis. Diterjemahkan oleh SGN Djiwa Darmaja. Gadjah Mada University Press. Yogyakarta.

Wodzicka, M., Tomaszewska, I.M. Mastika, A. Djajanegara, S. Gardiner dan T.R. Wiradarya, 1993. Produksi Kambing dan Domba di Indonesia. UNS Press. Surakarta.

Zain, M., 1999. Pengaruh taraf bungkil biji kapok dalam ransum kambing perah laktasi terhadap kecernaan dan karakteristik kondisi rumen. Jurnal Peternakan dan Lingkungan. 5:32-34. Universitas Padjadjaran Press. Bandung. 